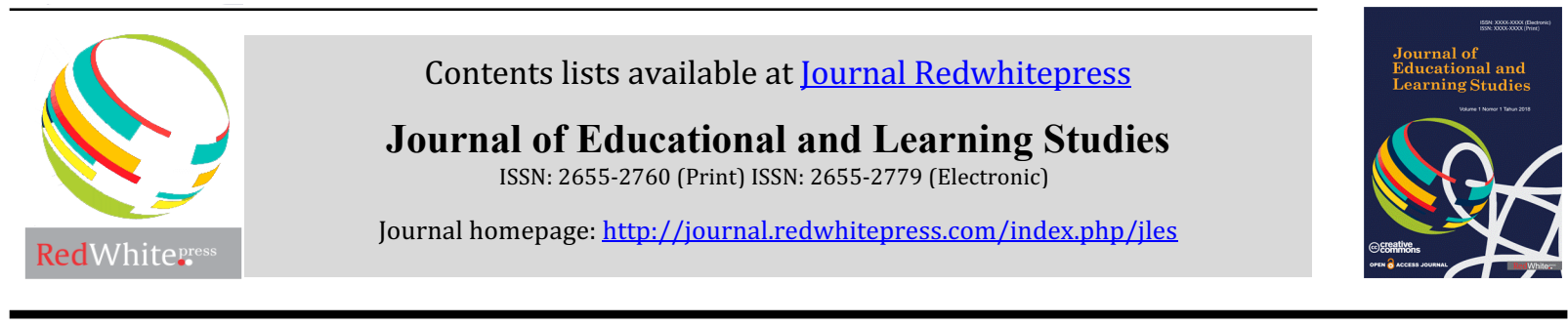

\title{
Effectiveness of Cognitive Behavior Therapy in Improving Students' Understanding of Bullying
}

\author{
Muslim $^{1}$, Neviyarni ${ }^{2}$, Yeni Karneli ${ }^{3}$ \\ ${ }^{123}$ Universitas Negeri Padang
}

\begin{tabular}{|c|c|}
\hline Article Info & ABSTRACT \\
\hline Article history: & \multirow{8}{*}{$\begin{array}{l}\text { The aim of this study was to examine the effectiveness of counseling through } \\
\text { cognitive behavioral therapy in improving students' understanding of bullying. } \\
\text { This research is a Quasi-Experiment with the Time Series Design. The research } \\
\text { subjects were } 10 \text { students, selected through Purposive Sampling techniques. } \\
\text { The research instrument used therefore was the scale of understanding bullying } \\
\text { with reliability of } 0.900 \text {, and the data were analyzed using the Wilcoxon } \\
\text { Signed Ranks Test through SPSS version 20.0. Based on the findings, } \\
\text { counseling through cognitive behavioral therapy is highly effective in } \\
\text { increasing students' understanding of bullying. This intervention aims to teach } \\
\text { students a variety of skills to overcome their problems, thereby helping them to } \\
\text { develop adaptive lifestyles. }\end{array}$} \\
\hline Received Jan $9^{\text {th }}, 2019$ & \\
\hline Revised Mar 23 $3^{\text {th }}, 2019$ & \\
\hline Accepted Aug 26 ${ }^{\text {th }}, 2019$ & \\
\hline Keyword: & \\
\hline Bullying & \\
\hline Counseling Cognitive Behavior & \\
\hline & \\
\hline
\end{tabular}

C 2019 The Authors. Published by Redwhitepress.

This is an open access article under the CC BY-NC-SA license

(https://creativecommons.org/licenses/by-nc-sa/4.0/

\section{Corresponding Author:}

Muslim,

Universitas Negeri Padang

Email: muslimsaragih27@gmail.com

\section{Introduction}

Bullying is a repeated physical or verbal behavior which psychologically harms the victim. According to Litwiller \& Brausch (2013) and Murphy, Xu, \& Kochanek (2012), latest research on the level of bullying shows that around $20-35 \%$ of adolescents are involved, as bullies, victims or both. Usually, the victims are unable to defend themselves because they are physically or mentally weak, thereby triggering stress due to fear. Bullying has the capacity to disrupt the daily lives as well the learning activities of students.

According to Sutton, Smith, \& Swettenham (1999), students' lack ofunderstanding of the impact of bullying on victims is an important factor which triggers it in schools. These impacts on victims, such as decrease in interest in learning as well as learning motivation, are associated with increase in depression and aggression, decrease in academic values, as well as the unwillingness to go to school among affected students. The aggressive acts of perpetrators usually cause violence for victims which could harm them or lead to injury. Rahmawati (2017) explains that there are similarities in the opinion of teachers about the characteristics of students who are bullying, and bullies usually are students who tend to have problems in school such as with low achievement, families with broken home, etc.

News about bullying concentrates more on the perpetrators and victims. Also, there are some behaviors that primarily support bullying even within the school environment but eradicating it becomes difficult due to the ignorance of such behaviors. Hence, solving the problem of bullying in school is a shared responsibility, and in this case, teachers' understanding could help students in desisting from it. According to Sucipto (2016), it is important to build awareness of the act, thereby aid its understanding and impact on all school stakeholders. 
also explained that students' low and wrong understanding of bullying, are the major causes of the act in schools, such that students consider it as a natural thing to do.

Additionally, the act of bullying can occur anywhere and anytime, and the action is increasing from year to year in various forms. It is also experienced in the school picked as the location of this study. Observations and series of interviews with teachers at BK SMP Negeri 13 Padang, revealed that there have been several cases of bullying which were handled by the teachers. In addition, there are currently students who beat, threatened, ostracized, mocked parents' names, ask for money forcefully from other students and other verbal and nonverbal forms of bullying others.

Data also revealed that the teachers have not put in much efforts in improving students' understanding of bullying, although the first semester program of 2016/2017 school year had some topics to be handled by the guidance and counseling department, in relations to finding a lasting solution to it. Services provided by the counselors are in the form of individual information and guiding programs. However, despite the fact that information services have been provided to all students, some still engage in bullying. The major factor responsible for the increasing cases in the school is the lack of students' understanding of its effects and the fact that many students consider bullying as a natural thing, just to joke and not hurt the victim.

Also, the act of bullying is influenced by the understanding and beliefs about it, where this understanding directly affect students' behavior towards bullying. Generally, students engage in the act due to the fact they do not fully understand its negative effects on the victims. Some of these students do not see it as a behavior which is capable of hurting other people both physically, verbally and nonverbally, and feel it is a means of catching fun with their friends. However, bullying among teenagers has been in different forms, with different levels of prevalence for various forms. According to (Wang et al., 2009), behavior bullying generally takes one of the four forms: physical (assault), verbal (threat or humiliation), relational (exception or spreading rumors), and Cyber (aggressive texts or posts social network). Dalimunthe, R. Z., Marjohan. (2014) explains several factors responsible for behavior bullying among students, namely: (1) family, (2) association, and (3) school environment. In addition, assumes that bullying is caused by an incorrect understanding of its actions, hence, students consider it as a natural thing to do. Futhermore, some schools tend to cover up cases of bullying, considering the fact that it could give the schools bad reputations if it is made public.

The impact of behavior bullying on a student is that those who are familiar with it tend to extend it to others. Also, McEvoy \& Erickson (Kathryn, G \& David, 2011) explain that children who experience behavior bullying tend to repeat it or eventually withdraw from the social environment. According to Kathryn, $G \&$ David (2011), the continuing effects it has include adolescents venting their feelings through anti-social behaviors accompanied by positive aggressiveness orl hold back and internalize their feelings with the consequences of developing depression and the emergence of thoughts about suicide.

According to Sullivan (2000), the targeted students have some characteristics, which include: (1) Having abnormalities, being too spoiled, whiny and self-assertive, (2) physical features such as weakness, disability, and negative social skills, (3) provocative, likes to hurt people, (4) characteristics existing in their personality such as shyness, being passive, and self-negativity, (5) always aloof, ie do not have friends to relate with, and (6) peonew students who move from another school or new students who are just admitted.

The conditions observed further emphasize the need for school counselors to improve students' understanding of behavior bullying. One way of achieving this is by utilizing existing approaches to counseling services. These approaches could help to overcome students' problems and develop their abilities, individually or as groups and one of such is the cognitive behavior therapy (CBT). )

Judith Beck (2011), defines CBT as a counseling approach designed to solve individual problems at this time by means of cognitive restructuring and deviant behavior. CBT is a therapy that directs and modifies the function of thinking, feeling and acting by emphasizing the brain as an analyzer, making decisions, asking questions, acting, and deciding again. Then, the aspect of behavior is directed at building a good relationship between problem situations and the reaction that follows.

Cognitive therapy uses a combination of three approaches namely biomedical, intrapsychic and environmental. According to Oemarjoedi (2003), CBT is a behavior modification therapy that uses cognition as the key to behavior change, and therapists help by replacing clients' bad thoughts and beliefs with better constructs of mindset. Furthermore, Spiegler \& Guevremont (Elna Yuslaini Siregar \& Rodiatul Hasanah Siregar, 2013) suggest that CBT is a psychotherapy which focuses on cognition modified directly, that is, when people change their minds maladaptifnya (maladaptive thought) then indirectly also change the behavior which is visible (overreaction).

CBT aimed at helping individuals in creating positive emotional situations, thereby implementing specific strategies, such as cognitive restructuring. Beck (Elna Yuslaini Siregar \& Rodiatul Hasanah Siregar, 2013) identifies that the main purpose of CBT is to help individuals change irrational thoughts or cognitions into more rational thinking. Also, Oemarjoedi (2003) states that the purpose of CBT is to help clients to oppose wrong thoughts and emotions by presenting evidence that contradicts their beliefs about the problem at

Journal homepage: http://journal.redwhitepress.com/index.php/jles 
hand. The approach encourages individuals to learn and have control over their thought patterns and feelings, thereby living a better life through a realistic and balanced mindsets (Christine Wilding, 2010).

It is very important that the implementation of counseling is tailored in line with the characteristics or problems of the client. This is achieved through the understanding of the principles underlying CBT. Understanding of these principles is expected to help the counselor in understanding the concepts and strategies in planning the counseling process from each session, and the application of CBT techniques. Furthermore, CBT has several basic principles and these include (1) cognitive principles, (2) behavioral principles, (3) principles continuum, (4) principles here and now, (5) the principle of the interacting system.

The implementation of CBT counseling could be achieved through settings individual (individual counseling), groups (group counseling/counseling), as well as classical (giving information) thereby alleviating the problems faced by the individual. According to Anderson \& Rees (2007), counseling a group through CBT is more effective in reducing controlled obsessive-compulsive disorder. In this study, the implementation of CBT counseling was also carried out using groups and according to Winkel (2004), group guidance is defined as a guidance given to a person or group of people in order to develop into an independent person.

McLeod, (2006) states that CBT counselors or therapists normally use various intervention techniques to get behavioral agreements with their clients, these include: (1) arranging irrational beliefs, (2)bibliotherapy, (3) role play, (4) trying to use different kinds of self-statements in real situations, (5) measuring feelings, for example by measuring the anxiety currently experienced on a scale of $0-100$, (6) stopping the mind from having negative thoughts and turn it into positive, (7) desensitization systematic, (8) social skills training, (9) assertiveness skill training, (10) home assignments, (11) In vivo exposure, and (12) covert conditioning.

Based on these, researchers on this subject matter are more interested in conducting research on counseling which focuses on the use of cognitive behavior therapy in increasing students' understanding of bullying. Therefore, the aim of this study is to see the difference in the scores of understanding of bullying students 'before and after the treatment with cognitive behavior therapy.

\section{Method}

This is a quantitative research with the approach of quasi-experiment. A design classified as a quasiexperiment is the one involving time series. The experiment was conducted with 3 pretests before and 3 posttests after treatment, in order to find out the causal relationship. In the implementation of this design before giving the treatment, the first thing that was done was a thorough observation of the subjects several times in order to known group trends. Then after the treatment was given, the researchers carried out more observations using the same instrument as before treatment. The subjects of this study were students of class VIII-5, and the samples were selected through purposive sampling technique. The instrument used is understanding bullying. The research instrument uses the scale of attitudes toward bullying which has met the requirements of validity and reliability. The level of significance set was $\mathrm{p}>0.05$ while the reliability of the research instrument was 0.90 . Then, the data analysis was conducted using the Wilcoxon Signed Rank Test.

\section{Results and Discussions}

Data from the research results described are those which involve understanding bullying. The experimental group data had a score of 89.4 (pretest 1), 91.5 (pretest 2), and 92.8 (pretest 3 ), while the average score obtained was 91.2. Based on the results from the pretest, it can be concluded that the average results of understanding bullying by the students was very low. However, the understanding increased at all the levels of posttest after treatment with the following figures124.6 (posttest 1), 128.9 (posttest 2) 128.9, and 131.7 (posttest 3 ). Based on these, it can be concluded that there were significant improvements in the understanding of bullying by the students as shown in Table 1 .

Furthermore, there are differences in the average score of students' understanding of bullying in pretests 1,2 and 3. This is an indication of some internal and external validity which cannot be controlled by researchers and participate in influencing the understanding of bullying students who are the research subjects. 


\begin{tabular}{cccccc}
\hline \multicolumn{7}{c}{ Table 1. Results of pretest and posttest Understanding Bullying Student } & \\
\hline Test & Score & Category & Test & Score & Category \\
\hline pretest 1 & 89.4 & Low & posttest 1 & 124.6 & High \\
\hline pretest 2 & 91.5 & Low & posttest 2 & 128.9 & High \\
\hline pretest 3 & 92.8 & Average & posttest 3 & 131.7 & Very High \\
\hline Total Score & $\mathbf{2 7 3 . 7}$ & - & Total Score & $\mathbf{3 8 5 . 2}$ & - \\
\hline Average Score & $\mathbf{9 1 . 2}$ & Low & Average Score & $\mathbf{1 2 8 . 4}$ & High \\
\hline
\end{tabular}

Also, there was increment from posttest 1 to 2 and same with posttest 3 . This is also influenced by internal and external validity which contributes to the understanding of bullying students treated with counseling cognitive behavior therapy.

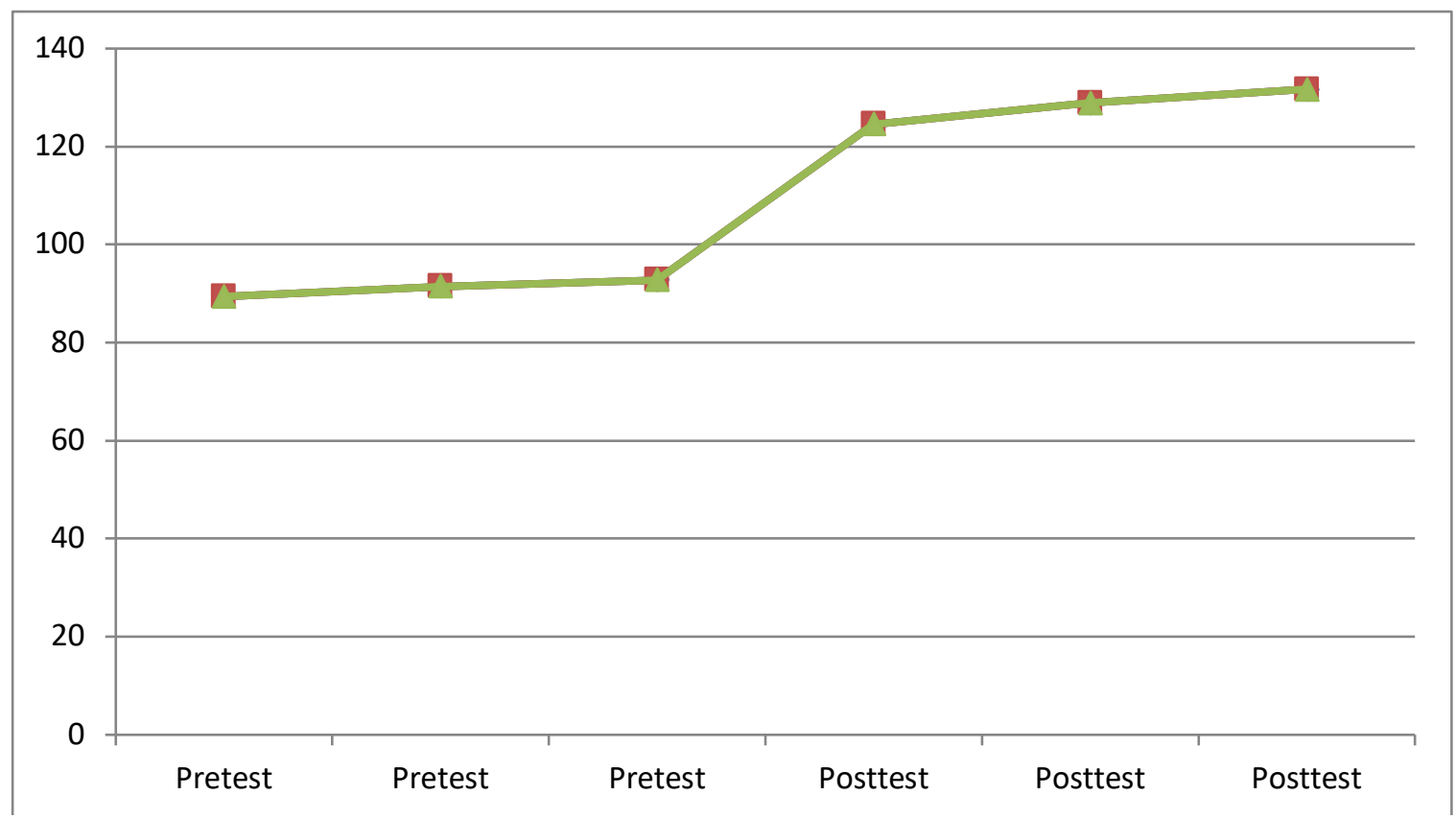

Figure 1: Graph of Understanding of Bullying

Based on the diagram above, it is obvious that each student experiences an increase in the score of understanding bullying after undergoing the given counseling using cognitive behavior therapy. The graph further explains that there is a more significant increase after being given treatment. This shows that counseling with cognitive behavior therapy is very effective in increasing students' understanding of bullying. Then in addition to the treatment given to the research subjects, some internal and external validity also contributed to the increase in the comprehension scores both in posttest 2 and 3.

The hypothesis testing was conducted by analyzing the pretest and posttest results using the Wilcoxon Signed Ranks Test. A summary of the calculation of hypothesis testing is shown on Table 2 below:

Table 2. Wilcoxon Signed Ranks Test

\begin{tabular}{lr}
\hline \multicolumn{2}{c}{ Test Statistics $^{\mathrm{a}}$} \\
\hline & \begin{tabular}{c} 
ResultsPosttest- $_{\text {Pretest }}$ \\
\hline $\mathrm{Z}$
\end{tabular} \\
\hline Asymp. Sig. (2-tailed & $-2,812^{\mathrm{b}}$ \\
\hline
\end{tabular}

Analysis using the Wilcoxon Signed Rank Test shows that there was a significant difference in the understanding bullying by the students before and after undergoing the counseling through cognitive behavior therapy. The probability figure shows Asymp. Sig. (2-tailed) of 0.005 , or probability below 0.05 alpha 
$(0.005 \leq 0.05)$. Based on these results, the $\mathrm{H}_{0}$ is rejected and $\mathrm{H}_{1}$ accepted, which means that there are significant differences between the understanding bullying of students before and after treatment.

The results of this study prove that counseling through cognitive behavior therapy effectively improves the understanding of bullying by students. There was an increase in the understanding score of all the members of the group from the categories low and average to high and very high. Hence, cognitive behavior therapy is one approach in counseling designed to solve the problem of counselees through cognitive restructuring and deviant behavior. The counseling process is based on students' conceptualization or understanding of specific beliefs and patterns of counselee behavior. The goal of counseling through CBT is the emergence of cognitive and behavioral restructuring towards a better direction and this approach is one of the moste effective strategies in the implementation of counseling in an effort to improve understanding of bullying students.

Group counseling, in general, is a series of activities give the experience of students interacting with each other within a particular group, solving a problem together, and exchanging ideas, thereby changing perceptions, views, and attitudes towards the problem or topic being discussed. Through the setting up of groups, students gain new understanding, and therefore change their attitudes and views on bullying. After students were given the counseling through cognitive behavioral therapy, the scorest improved from low to high category. Also, the difference in the mean score of understanding of bullying before and after being given treatment is quite high and significant. The differences in these scores are the results of being given the counseling through cognitive behavior therapy.

The effectiveness of counseling through cognitive behavioral therapy in increasing students' understanding of bullying is also seen from the results of the study conducted byPambudhi (2016), entitled "The Effectiveness of Group Cognitive Behavior Therapy (GCBT) in Reducing Anxiety in Facing Executors in Respect of Bullying Victims Bullying". The results of this study prove that counseling through cognitive behavior therapy is effective in reducing behavior anxiety of bullying students. In addition, the results of the research conducted by Yahya AD. (2016), entitled "The Influence of Counseling Cognitive Behavior Therapy (CBT) with Techniques Self Control to Reduce Aggressive Behavior of Grade VIII Students at Bandar Lampung Middle School 2016/2017 Academic Year", also prove that approaching counseling with cognitive behavior therapy is effective in reducing the aggressive behavior of adolescents in school. Cognitive behavior therapy emphasizes that problematic behavior is caused by irrational or maladaptive thinking, therefore, its focus of treatment is solving this type of thinking. According to, what an individual needs to overcome their emotional and behavioral problems is to change the deviant beliefs developed by them. Irrational or maladaptive thinking leads to self-hate which usually impacts on self-destructive behavior and then the individual starts hating others, thereby thinking and acting irrational to others, continuously following the circle.

According toRahmawati (2017), bullying is defined as repeated aggression carried out by one or more people who aim to harm or disturb others physically, verbally or psychologically. Students who tend to engage in bullying begins with hatred of themselves, both because of their physical, family, and school environment and the desire to increase the popularity of the perpetrators among their fellow student.

Additionally, counseling through cognitivebehavior therapy emphasizes the problematic behavior is caused by negative or irrational thinking which the individual is not able to interpret the conditions faced, hence, is not able to focus on the treatment except through CBT. The results of the study conducted by study entitled "The Effectiveness of Cognitive Behavior Therapy and Rational Emotive Behavior Therapy on Symptoms and Ability to Control Emotions in Clients Violence Behavior" shows that CBT and REBT have the capacity to reduce or control emotions in clients violent behavior.

The process of implementing counseling through CBT is carried out in 5 stages, namely, (1) assessment or diagnosis, (2) cognitive approach, (3) status formulation, (4) focus of therapy, and (5) core beliefs. However, the treatment given in this study was conducted with three topics: (1) understanding and impact of bullying, (2) forms of bullying, and (3) fostering a sense of empathy. In addition, it is evident that students' understanding of bullying is aided with counseling through cognitive behavioral therapy. The above reality in accordance with the opinion of Christine \& Wilding (2010) which explains that education models of cognitive behavioral therapy teach individuals to be themselves, and are used in daily life in accordance with the problems faced by the individuals, thereby controlling their thoughts and behavior, as well as improving their quality of life .

Based on the above described, there is need for the counselor to be more creative in providing guidance and counseling services especially with the group guidance. Also, the use of cognitive behavioral therapy in conseling has been adjusted to various criteria with the aim of supporting the teaching objectives carried out by the BK teachers.

Based on the results of data analysis, it can be concluded that counseling with cognitive behavior therapy is very effective in increasing students' understanding of bullying. This effectiveness is seen from the increase in the scores. Thus, there is need to creatively carried out counseling through cognitive behavioral therapy with the aim of increasing students' understanding of bullying. 


\section{Conclusions}

Counseling through cognitive behavior therapy helps to direct and modify the functions of thinking, feeling and acting by emphasizing the brain as an analyzer, by making decisions, asking questions, acting and deciding again. Additionally, it is designed to solve individual problems by means of cognitive restructuring and deviant behavior.

In general, the results of this study shows that counseling is more effective with cognitive behavior therapy as it helps in increasing students' understanding of bullying. Furthermore, the findings of this study reveal that there are differences in the students' understanding before and after being given treatment, in which the average results increased after undergoing counseling through cognitive behavior therapy. Before the treatment, i.e, pretest, the average students' understanding of bullying was $92.8 \%$, dominated by students in the low category. However, the average level of understanding increased to $124.6 \%$ after posttest.

Therefore, it can be concluded that counseling through cognitive behavioral therapy is needed by students to increase their understanding of bullying, thereby creating a program capable of helping students to avoid attitudes and behaviors that could lead to bullying in schools.

\section{References}

Anderson, R. A., \& Rees, C. S. (2007). Group versus individual cognitive-behavioral treatment for obsessivecompulsive disorder: A controlled trial. Behaviour Research and Therapy, 45(1), 123-137. https://doi.org/10.1016/j.brat.2006.01.016

Astuti, P. R. (n.d.). Meredam Bullying: 3 Cara EfektifMengatasi Kekerasan pada Anak. Jakarta: Grasindo.

Christine Wilding, A. M. (2010). Cognitive Behavior Therapy (A. Fuandy, ed.). Jakarta: Jakarta. Indeks.

Dalimunthe, R. Z., Marjohan., \& S. (2014). Kontribusi Pengasuhan Orangtua dan Self-Esteem terhadap Perilaku Bullying. Ejournal.Unp.Ac.Id/Index.Php/Konselor, 3(4), 158-167.

Elna Yuslaini Siregar, \& Rodiatul Hasanah Siregar. (2013). Penerapan Cognitive Behavior Therapy (CBT) Terhadap Pengurangan Durasi Bermain Games Pada Individu Yang Mengalami Games Addiction. Jurnal Psikologi UIN Sultan Syarif Kasim Riau, 9(Juni), 17-24.

Judith Beck. (2011). Cognitive Behavior Therapy, Second Edition - Basics and Beyond. In New York (Vol. 6). New York: The Guilford Press.

Kathryn, G \& David, G. (2011). Konseling Remaja. Yogyakarta: Pustaka Pelajar.

Litwiller, B. J., \& Brausch, A. M. (2013). Cyber Bullying and Physical Bullying in Adolescent Suicide: The Role of Violent Behavior and Substance Use. Journal of Youth and Adolescence, 42(5), 675-684. https://doi.org/10.1007/s10964-013-9925-5

McLeod, J. (2006). Pengantar Konseling: Teori dan Studi Kasus (A.K. Anwar). Jakarta: Kencana.

Murphy, S. L., Xu, J. Q., \& Kochanek, K. D. (2012). Deaths: preliminary data for 2010. National Vital Statistics Reports. Natl Center Health Stat, 60(4), 1-69. Retrieved from https://www.cdc.gov/nchs/data/nvsr/nvsr60/nvsr60_04.pdf

Oemarjoedi, A. K. (2003). Pendekatan Cognitive Behavior Dalam Psikoterapi. Jakarta: Creative Media.

Pambudhi, Y. A. (2016). Efektivitas Group Cognitive Behavior Therapy (CBT) Dalam Menurunkan Kecemasan Menghadapi Pelaku Bullying Ditinjau Dari Harga Diri Pada Korban Bullying. Jurnal Ilmiah Psikologi Terapan, 3(1), 18-31. https://doi.org/10.22219/JIPT.V3I1.2124

Rahmawati, S. W. (2017). Peran Pengasuhan Holistik Terhadap Altruisme dan Bullying. Humanitas, $14(1), 10$. https://doi.org/10.26555/humanitas.v14i1.4316

Sucipto, S. (2016). Bullying dan Upaya Meminimalisasikannya. PSIKOPEDAGOGIA Jurnal Bimbingan Dan Konseling, 1(1). https://doi.org/10.12928/psikopedagogia.v1i1.2566

Sudiatmika, I. K., Keliat, B. A., \& Wardani, Y. (n.d.). EFEKTIVITAS COGNITIVE BEHAVIOUR THERAPY DAN RATIONAL EMOTIVE BEHAVIOUR THERAPY TERHADAP GEJALA PADA KLIEN PERILAKU KEKERASAN. 1-10.

Sullivan, K. (2000). The Anti Bullying Handbook. Auckland: Oxford University Press. 
Sutton, J., Smith, P. K., \& Swettenham, J. (1999). Social cognition and bullying: Social inadequacy or skilled manipulation? British Journal of Developmental Psychology, 17(3), 435-450. https://doi.org/10.1348/026151099165384

Winkel, W. S. (2004). Bimbingan dan Konseling di Institusi Pendidikan. Yogyakarta. Media Abadi.

Yahya AD., M. (2016). Pengaruh Konseling Cognitif Behavior Therapy (Cbt) Dengan Teknik Self Control Untuk Mengurangi Perilaku Agresif Peserta Didik KELAS VIII DI SMPN 9 Bandar Lampung Tahun Pelajaran 2016/2017. Jurnal Bimbingan Dan Konseling, 3(2), 187-200. 